\title{
Characterization of pectinase activity for enology from yeasts occurring in Argentine Bonarda grape
}

\author{
María Gabriela Merín ${ }^{1,2}$, María Carolina Martín ${ }^{1,2}$, Kalliopi Rantsiou ${ }^{3}$, Luca Cocolin ${ }^{3}$, \\ Vilma Inés Morata de Ambrosini, ${ }^{1,2}$ \\ ${ }^{1}$ Facultad de Ciencias Aplicadas a la Industria, Universidad Nacional de Cuyo, Mendoza, Argentina. \\ ${ }^{2}$ Consejo Nacional de Investigaciones Científicas y Técnicas, Buenos Aires, Argentina. \\ ${ }^{3}$ Dipartimento di Scienze Agrarie, Forestali e Alimentari, Università di Torino, Torino, Italy.
}

Submitted: February 19, 2014; Approved: February 2, 2015.

\begin{abstract}
Pectinolytic enzymes are greatly important in winemaking due to their ability to degrade pectic polymers from grape, contributing to enhance process efficiency and wine quality. This study aimed to analyze the occurrence of pectinolytic yeasts during spontaneous fermentation of Argentine Bonarda grape, to select yeasts that produce extracellular pectinases and to characterize their pectinolytic activity under wine-like conditions. Isolated yeasts were grouped using PCR-DGGE and identified by partial sequencing of $26 \mathrm{~S}$ rRNA gene. Isolates comprised 7 genera, with Aureobasidium pullulans as the most predominant pectinolytic species, followed by Rhodotorula dairenensis and Cryptococcus saitoi. No pectinolytic activity was detected among ascomycetous yeasts isolated on grapes and during fermentation, suggesting a low occurrence of pectinolytic yeast species in wine fermentation ecosystem. This is the first study reporting $R$. dairenensis and $C r$. saitoi species with pectinolytic activity. $R$. dairenensis GM-15 produced pectinases that proved to be highly active at grape $\mathrm{pH}$, at $12{ }^{\circ} \mathrm{C}$, and under ethanol and $\mathrm{SO}_{2}$ concentrations usually found in vinifications (pectinase activity around $1.1 \mathrm{U} / \mathrm{mL}$ ). This strain also produced cellulase activity at $12{ }^{\circ} \mathrm{C}$ and $\mathrm{pH} 3.5$, but did not produce $\beta$-glucosidase activity under these conditions. The strain showed encouraging enological properties for its potential use in low-temperature winemaking.
\end{abstract}

Key words: Aureobasidium pullulans, Cryptococcus saitoi, pectinolytic activity, Rhodotorula dairenensis, winemaking.

\section{Introduction}

Pectinolytic enzymes are polysaccharidases that degrade pectins present in middle lamella and primary cell walls of plants. This ability is widely used in winemaking as pectinases can help to improve liquefaction, juice yield, clarification, filterability, and to increase the release of color and flavor compounds entrapped in grape skins (Fleet, 2008; Alimardani-Theuil et al., 2011; Martín and Morata de Ambrosini, 2014).

Grape skin forms a physical barrier to diffusion of anthocyanins, tannins and aroma contained in the skin cells. The permeability of skin cell walls to these compounds can be increased by partial hydrolysis of their struc- tural polysaccharides (pectins, cellulose and hemicelluloses), a process that can be facilitated by pectinolytic preparations. These enzymes are complex mixtures mainly comprised of pectinases, but also other desirable activities like cellulases, hemicellulases and acid proteases. Cellulases and hemicellulases are also responsible for an increase in the extraction of grape juice, and the improvement in the clarification of wines (Romero-Cascales et al., 2008).

Nowadays, commercial pectinase preparations are obtained from fungi and apart from desirable activities, they generally contain undesirable enzymes like pectinesterase (Alimardani-Theuil et al., 2011) and $\beta$-glucosidase (Romero-Cascales et al., 2008) that can negatively affect 
the quality of wines. Yeasts are known to produce mostly polygalacturonases (Alimardani-Theuil et al., 2011), and they could therefore be a preferable source of pectinases. Considering the key role of yeasts in winemaking, selection of pectinolytic yeasts for enology is an alternative approach to fungal pectinases. Although some pectinolytic wine yeasts have already been described (Fernández et al., 2000; Fernández-González et al., 2004), further studies are needed.

"San Rafael" Designation of Origin (DO), an area in central-west Argentina, represents an important wine region in South America. Despite its long viticulture and enology history, very little is known about the microorganisms involved in spontaneous fermentations. Currently, Argentine Bonarda is one of the red grape varieties with increasing enological interest in the country.

Cold-active enzymes are attractive for usage in food industry since low-temperature conditions favor conservation of sensory and nutritional properties in the product (Sahay et al., 2013). A previous study reported cold-active pectinase activity by yeasts isolated from wine grapes (Merín et al., 2011). However, the presence of pectinolytic yeasts during fermentation and their enzymatic activities under winemaking conditions have not been described.

This study reports the occurrence of pectinolytic strains among representative yeasts isolated at different stages during spontaneous fermentation of Argentine Bonarda grape. And it focuses on selection and characterization of their enzymatic behavior under wine-like conditions $\left(\mathrm{pH} 3.5,12\right.$ and $28^{\circ} \mathrm{C}$, ethanol and $\mathrm{SO}_{2}$ ) for their potential use in winemaking.

\section{Materials and Methods}

\section{Study area, sampling and fermentation}

Grape samples (Vitis vinifera L.) of cv. Argentine Bonarda were collected from Cuadro Benegas viticultural region (lat. $34.62^{\circ} \mathrm{S}$, long. $68.45^{\circ} \mathrm{W}$ ) in San Rafael DO, Mendoza, Argentina, during the 2009 vintage.

Representative bunches of healthy grapes were aseptically hand harvested, transported to the laboratory and kept cold until their study. The collected grapes were crushed to conduct the spontaneous fermentation in $1 \mathrm{~L}$ Erlenmeyer flasks containing $800 \mathrm{~mL}$ of must (reducing sugars $220 \mathrm{~g} / \mathrm{L}$; titratable acidity $4.6 \mathrm{~g} / \mathrm{L}$; yeast assimilable nitrogen (YAN) $310 \mathrm{mg} / \mathrm{L} ; \mathrm{pH} 4.2$ ). Progress of the alcoholic fermentation was monitored daily by measuring weight loss using flasks with stoppers containing a Müller valve that allows only $\mathrm{CO}_{2}$ to escape from the system. Fermentations were carried out in duplicate at $25 \pm 1{ }^{\circ} \mathrm{C}$ until constant weight for two consecutive days.

\section{Yeast isolation}

Before the grape crushing, 10 berries were placed in a flask containing $10 \mathrm{~mL}$ of sterile peptone-water $(0.1 \%$, $\mathrm{w} / \mathrm{v}$ ) and were shaken at $165 \mathrm{rpm}$ during $1 \mathrm{~h}$ at room temperature. Aliquots of adequate dilutions of both berry washing solution and grape must, sampled at $0,3,5,8$ and 12 days of fermentation, were plated onto WL Nutrient Agar. This medium allows presumptive discrimination among yeast species by colony morphology and color (Pallmann et al., 2001). Plates were incubated at $25^{\circ} \mathrm{C}$ for 5 days for colony development. A representative number of each colony type was recovered. Isolates were purified by streak plating and subcultured onto Yeast extract Peptone Dextrose (YPD: yeast extract, $10 \mathrm{~g} / \mathrm{L}$; peptone, $20 \mathrm{~g} / \mathrm{L}$; dextrose, $20 \mathrm{~g} / \mathrm{L}$; agar, $20 \mathrm{~g} / \mathrm{L}$ ) for subsequent identification.

\section{Molecular yeast identification}

Yeast isolates were examined with PCR-DGGE to group them according to their DGGE mobility and representative strains of each group were subsequently sequenced as described by Rantsiou et al. (2013). Isolates were subjected to DNA extraction and a DNA fragment from the D1-D2 loop region of the 26S rRNA gene was amplified by PCR using primers NL1GC/LS2 following the protocol proposed by Cocolin et al. (2000).

The DCode ${ }^{\mathrm{TM}}$ Universal Mutation Detection System (Biorad, USA) was used for DGGE analysis according to Cocolin et al. (2000) with minor modifications in the denaturing gradient (30 to $50 \%$ urea-formamide) and the electrophoresis conditions (constant voltage of $130 \mathrm{~V}$ for $4 \mathrm{~h}$ ). To obtain species identification, PCR amplification of representative colonies from each migration-specific group was conducted by using primers NL1/NL4 (Kurtzman and Robnett, 1998). PCR products were purified using the QIAquick ${ }^{\circledR}$ PCR Purification Kit (Qiagen, Germany) and sequencing was carried out at MWG Biotech (Germany) and CERELA (Argentina). Strains were identified by searching the GenBank database with the BLAST program (http://www.ncbi.nlm.nih.gov).

\section{Screening of pectinolytic activity among isolated yeasts}

The ability of isolated yeasts to hydrolyze pectin was assayed using the Petri dish method according to Merín et al. (2011). The isolates were point-inoculated onto a mineral medium containing $0.2 \%(\mathrm{w} / \mathrm{v})$ citric pectin as carbon source, at $\mathrm{pH} 4.5$, and incubated at $28^{\circ} \mathrm{C}$ for $48-72 \mathrm{~h}$. Enzyme activity was evidenced by clear halos around the colonies against a purple-brown background after addition of Lugol's solution.

\section{Enzyme assays}

\section{Production of extracellular enzymatic extracts}

For enzyme production, yeasts showing pectinolytic activity on plates were inoculated in a basal liquid medium (containing per $\mathrm{L}$ of $50 \mathrm{mM}$ citric-citrate buffer: dextrose, $20 \mathrm{~g}$; soy peptone, $10 \mathrm{~g}$; meat peptone, $10 \mathrm{~g}$; yeast extract, $10 \mathrm{~g}$ ) at $\mathrm{pH} 3.5$, proximate to wine $\mathrm{pH}$. The cultures were 
incubated under shaking conditions (100 rpm) at 12 and $28^{\circ} \mathrm{C}$ for 5 or 3 days, respectively. Cells were removed by centrifugation $\left(5000 \mathrm{x} g, 15 \mathrm{~min}\right.$ at $\left.4{ }^{\circ} \mathrm{C}\right)$ and supernatants were filtered $(0.22 \mu \mathrm{m})$ to obtain cell-free supernatants (enzymatic extracts) on which all the enzymatic activities were assayed throughout this study.

The assessment of enzymatic activities in the present work was always carried out at the same temperature of the enzymatic production, at 12 or $28^{\circ} \mathrm{C}$, as appropriate.

\section{Pectinolytic activity}

Pectinolytic activity was assayed by measuring the amount of reducing sugars released from a pectin dispersion $(0.25 \%$ pectin in $50 \mathrm{mM}$ citric-citrate buffer, $\mathrm{pH} 3.5)$ using 3,5-dinitrosalicylic acid (DNS) reagent (Miller, 1959). Galacturonic acid was used as standard (Sigma, USA). The reaction mixtures (enzymatic extract/substrate 1/10) were incubated at 12 or $28{ }^{\circ} \mathrm{C}$, at the corresponding enzyme production temperature, for $30 \mathrm{~min}$ as previously described (Merín et al., 2011). One pectinase unit (U) is defined as the enzymatic activity that releases $1 \mu \mathrm{mol}$ of reducing sugar per min under the assay conditions.

\section{Other cold-active hydrolytic activities of enological interest}

Cellulase and xylanase activities were assayed in enzymatic extracts obtained at $12{ }^{\circ} \mathrm{C}$ as described above by measuring the reducing sugars according to Miller (1959). Cellulase was measured using microgranular cellulose (Whatman CC41) and xylanase using birchwood xylan (Sigma, USA) as substrates at a concentration of $0.25 \%$ $(\mathrm{w} / \mathrm{v})$ in $50 \mathrm{mM}$ citric-citrate buffer $(\mathrm{pH} 3.5)$. The enzymatic reactions were carried out at $12^{\circ} \mathrm{C}$ for $30 \mathrm{~min}$. One cellulase or xylanase unit is defined as the enzymatic activity that releases $1 \mu \mathrm{mol}$ of reducing sugar (as glucose or xylose, respectively) per min under the assay conditions.

$\beta$-Glucosidase activity was assayed by incubating $100 \mu \mathrm{L}$ of enzymatic extract with $100 \mu \mathrm{L}$ of $15 \mathrm{mM} \mathrm{D-(+)-}$ cellobiose (Fluka, USA) solution in citric-citrate buffer $(\mathrm{pH}$ 3.5 ) at $12{ }^{\circ} \mathrm{C}$ for $30 \mathrm{~min}$. Glucose produced was quantified using the enzymatic colorimetric test (GOD-POD) (Arévalo-Villena et al., 2007). One $\beta$-glucosidase unit is defined as the enzymatic activity that releases $2 \mu \mathrm{mol}$ of glucose from cellobiose per min under the assay conditions.

Extracellular protease activity was assayed qualitatively by point-inoculation of yeasts on plates of skim milk agar and gelatin agar at $\mathrm{pH} 4.5$, according to the method described by Charoenchai et al. (1997). Skim milk agar plates were directly examined for clear zones surrounding yeast growth after incubation at $12{ }^{\circ} \mathrm{C}$ for 3-5 days, whereas gelatin agar plates were flooded with $10 \mathrm{~mL}$ acetic acid $(50 \mathrm{~g} / \mathrm{L})$ before examination for clear zones around the yeast cells.

Appropriate enzyme and substrate blanks, as well as calibration curves, were included in all quantitative enzymatic assays.
T. delbrueckii BTd259 (Maturano et al., 2012) was used as positive control for pectinolytic and other hydrolytic activities.

\section{Influence of enological parameters on pectinolytic activity}

The effects of ethanol, sulfur dioxide $\left(\mathrm{SO}_{2}\right)$ and a combination of ethanol and $\mathrm{SO}_{2}$ on pectinase activity were evaluated in cell-free supernatants (enzymatic extracts produced as described in previous section) under standard enzymatic assay conditions. The substrate was supplemented with ethanol and total $\mathrm{SO}_{2}$ at final concentrations of $15 \%$ (v/v) and $120 \mathrm{mg} / \mathrm{L}$, respectively, and reactions were carried out at 12 and $28^{\circ} \mathrm{C}$, as appropriate. Reaction mixtures assayed under the same conditions at their respective temperatures but in absence of ethanol and $\mathrm{SO}_{2}$ corresponded to the reference activity.

\section{Statistical analysis}

Analysis of variance (ANOVA) and Fisher's LSD test $(p<0.05)$ were applied to all experimental data, using STATGRAPHICS Plus 5.1 (Manugistics, Rockville, MD, USA). Data normality and variance homogeneity in the residuals were verified by modified Shapiro-Wilks and Levene's test, respectively.

\section{Nucleotide sequence and yeast strain accession numbers}

Partial sequence of the 26S rRNA gene of the most representative strains were submitted to the GenBank database available at NCBI under accession numbers: JF414133 (Saccharomyces cerevisiae), JF414134 (Candida zemplinina), JN637171 (Cryptococcus saitoi), JN637172 (Rhodotorula dairenensis).

The latter two strains were also deposited at the Banco Nacional de Microorganismos (BNM) Culture Collection (Buenos Aires, Argentina) under accession numbers: BNM 538 (Cryptococcus saitoi GM-4) and BNM 539 (Rhodotorula dairenensis GM-15).

\section{Results and Discussion}

\section{Isolation and identification of representative yeasts from Argentine Bonarda grape and fermenting must}

Alcoholic fermentation of Argentine Bonarda must was completed in 12 days. The red wine had a final $\mathrm{pH}$ of 4.1 and a final ethanol concentration of $11.7 \%$ (data not shown).

A total of 48 yeast colonies were isolated from grape surface, fresh must and spontaneous fermentation on WL medium. The 22 colonies isolated from grapes and must comprised 8 groups with different morphology. During the fermentation process, the diversity of the yeast colony morphology decreased and only 6 different types were observed. Consequently, the 48 colonies were classified into 14 morphological groups (Table 1), characterized by their 
Table 1 - Identification at species level of morphological groups of yeasts isolated from grapes, fresh must and fermenting must, based on the migration of the bands obtained by PCR-DGGE.

\begin{tabular}{llccl}
\hline Morphological group & Isolation source of yeast groups & DGGE pattern & DGGE gel lane & Species identification $^{\text {a }}$ \\
\hline 7,11 & Grape, fresh must, fermenting must & I & 1,5 & Hanseniaspora sp. \\
$10,12,13,14$ & Fermenting must & II & $2,6,7,9$ & Saccharomyces cerevisiae \\
1,2 & Grape & III & 3,4 & Rhodotorula dairenensis \\
9 & Fermenting must & IV & 8 & Candida zemplinina \\
8 & Grape, fresh must, fermenting must & V & 10 & Metschnikowia sp. \\
$3,4,5$ & Grape, fresh must & VI & $11,12,13$ & Aureobasidium pullulans \\
6 & Grape & VII & 14 & Cryptococcus saitoi \\
\hline
\end{tabular}

${ }^{a}$ One representative isolate from each DGGE pattern was identified by sequencing of the D1-D2 loop region of 26S rRNA gene and comparison with BLAST tool in GenBank.

specific color, consistency and surface, as previously described (Pallmann et al., 2001; Urso et al., 2008).

All the colonies of each morphological pattern were subjected to PCR-DGGE to establish species-specific migration groups. Profiles of each DGGE migration group are presented in Figure 1.

Seven different DGGE profiles were generated. Comigrating DGGE bands were considered to belong to the same species. After sequencing, 7 yeast genera were identified, corresponding to A. pullulans, $R$. dairenensis, $\mathrm{Cr}$. saitoi, $C$. zemplinina and $S$. cerevisiae species and Hanseniaspora/Kloeckera sp. and Metschnikowia sp. (Table 1). The identified yeasts are among the most frequently described on grape skins and fresh musts from diverse regions around the world (Merín et al., 2011; Barata et al.,

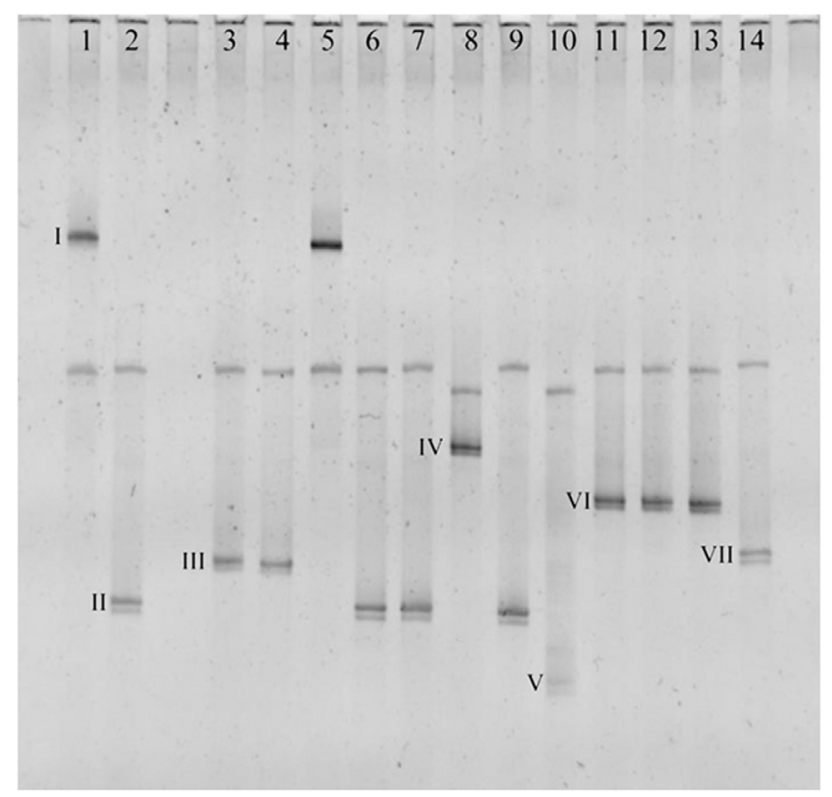

Figure 1 - DGGE profiles of yeasts isolated from Argentine Bonarda grapes and must during spontaneous fermentation. Correlations between lane designations and colony groups as well as Roman numerals and DGGE patterns are indicated in Table 1. The bands common to all isolates are single stranded DNA artifacts that were not influenced differentially by the gradient (Cocolin et al., 2000).
2012; Rantsiou et al., 2013), and during wine fermentation (Fleet, 2008; Urso et al., 2008; Rantsiou et al., 2013).

Occurrence of pectinolytic yeasts isolated during spontaneous fermentation of Argentine Bonarda grape

Out of 48 representative yeast isolates, $11(23 \%)$ belonging to 3 species showed pectinolytic activity on agar plates (Figure 2). According to a recent review by Alimardani-Theuil et al. (2011), of approximately 700 yeast species identified to date, only very few produce pectinolytic enzymes, which is in accordance with our results.

The total number of representative yeasts isolated from grapes, fresh must and fermentations is shown in Figure $2 \mathrm{~A}$. Among the yeast isolated from grapes and must, $A$. pullulans was the most abundant species with 8 isolates, followed by Hanseniaspora sp. with 6, Metschnikowia sp. and $R$. dairenensis, both with 3 , and $C r$. saito $i$ with 2 isolates.

Figure 2B shows that pectinolytic yeasts were only isolated from grape berry surfaces and fresh must. $A$. pullulans was the predominant pectinolytic species, representing $73 \%$ of the total number of isolates able to degrade pectin. Besides, all A. pullulans isolates produced pectinases. Similar results have previously been observed in wine grapes, with $A$. pullulans as the most frequent coldactive-pectinase-producing species (Merín et al., 2011, 2014), and in tropical environments where this species represented the highest proportion $(22 \%)$ of pectinolytic microorganisms (Buzzini and Martini, 2002). The results suggest that this pectinolytic microorganism is more prevalent in plant materials, soil and water.

The remaining pectinolytic species corresponded to the basidiomycetous yeasts $R$. dairenensis and $\mathrm{Cr}$. saitoi, representing $18 \%$ and $9 \%$ of the total pectinolytic isolates, respectively (Figure 2B). Two thirds of the representative isolates of $R$. dairenensis and half of the $C r$. saitoi isolates produced pectinases. Yeasts belonging to these two genera have previously been described as pectinolytic microorganisms (Federici, 1988; Nakagawa et al., 2004; Turchetti et 

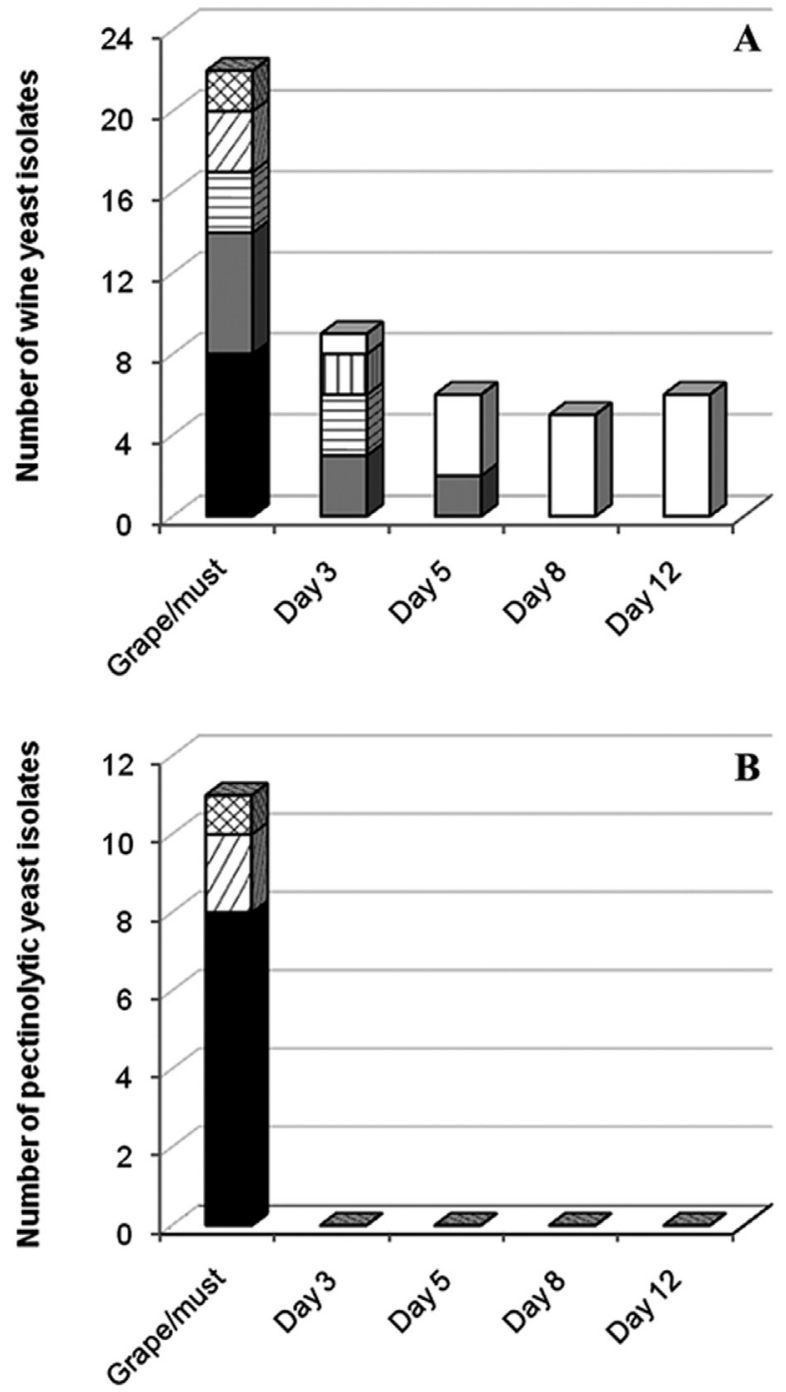

Figure 2 - Occurrence of pectinolytic yeasts among representative yeasts isolated from grapes, fresh must and fermentation (sampling time: days 3 to 12) of cv. Argentine Bonarda. Number of isolates of yeast species (A) and of pectinolytic yeast species (B) found on grapes and during spontaneous fermentation. Aureobasidium pullulans, Hanseniaspora sp., Metschnikowia sp., Rhodotorula dairenensis, Cryptococcus saitoi, Candida zemplinina and Saccharomyces cerevisiae.

al., 2008), particularly the species $R$. mucilaginosa (Vaz et al., 2011; Sahay et al., 2013) and R. glutinis (Taskin, 2013), which are phylogenetically closely related to $R$. dairenensis. Nevertheless, to our knowledge, this is the first study reporting pectinase activity by $R$. dairenensis and $C r$. saitoi species.

Most yeasts present on wine grape at harvest time and during fermentation belong to ascomycetous species (Fleet, 2008; Urso et al., 2008; Barata et al., 2012). Nevertheless, only a few ascomycetous species have been reported to produce pectinases in wine ecosystem such as Kluyveromyces, Candida, Metschnikowia and some S. cerevisiae strains (Fernández et al., 2000; Fernández-González et al., 2004).
In this study, no pectinolytic activity was detected among ascomycetous yeasts, either non-Saccharomyces or $S$. cerevisiae isolates (Figure 2). Comparable results have recently been obtained in studies of pectinolytic yeasts isolated from viticultural and enological environments (Merín et al., 2011, 2014), which are in agreement with findings reported by other authors. In an extensive screening survey, Buzzini and Martini (2002) demonstrated that pectinase activity was rarely found within ascomycetes in tropical environments, observing this ability in only $1.5 \%$ of studied ascomycetes. Charoenchai et al. (1997) did not detect pectinolytic activity in ascomycetous wine yeasts.

The fact that pectinolytic yeasts were only found on grape surfaces and must, whereas non-pectinolytic yeasts dominated the middle and last fermentation stages (Figure 2), suggests that a higher incidence of pectinolytic species may be observed in nutrient-poor environments like the grape surface and other plant surfaces, and in marine and glacial ecosystems (Nakagawa et al., 2004; Turchetti et al., 2008). It seems that pectinolytic yeasts play an ecological role on the grape surface since they can utilize pectin from cell walls releasing intracellular sugars to surface. Conversely, microorganisms in musts do not require pectinolytic activity to acquire carbon sources because of the abundance of readily usable sugars. This is consistent with results reported by Barata et al. (2012), who observed that the microbiota of truly intact berries after véraison is dominated by basidiomycetous yeasts (e.g. Cryptococcus spp., Rhodotorula spp., Sporobolomyces spp.) and A. pullulans; while visually intact berries may bear microfissures and softens, increasing nutrient availability and explaining the possible dominance by the oxidative or weakly fermentative ascomycetous populations (e.g. Candida spp., Hanseniaspora spp., Metschnikowia spp.) approaching harvest time.

According to our results, the microfissures and softens on visually intact berries could be due to the action of pectinases produced by pectinolytic yeasts on grapes, like A. pullulans and basidiomycetous yeasts found in this study, which would release intracellular substrates from grape, thus sustaining the growth of non-pectinolytic ascomycetous yeasts on the grape berry surface.

\section{Characterization of enzymatic activities}

\section{Hydrolytic activities under winemaking conditions}

All yeasts showing extracellular pectinase activity on plate were also assayed in liquid medium at $28{ }^{\circ} \mathrm{C}$ and $\mathrm{pH}$ 3.5 to select the best pectinolytic yeasts under winemaking conditions (data not shown). Of the 11 pectinolytic yeasts, two A. pullulans strains (GM-1 and GM-2) and two basidiomycetous yeasts ( $R$. dairenensis GM-15 and $C r$. saitoi GM-4) produced the highest activities at grape $\mathrm{pH}(0.967$, $1.325,1.260,0.930 \mathrm{U} / \mathrm{mL}$, respectively). These activities are higher than those produced by other yeasts, such as Saccharomyces strains: 0.107-0.679 U/mL (Oliveira et al., 
2006) and Zygoascus hellenicus strains: $0.025-0.220 \mathrm{U} / \mathrm{mL}$ (Ahansal et al., 2008). However, the pectinolytic activities cited were displayed at $\mathrm{pH}$ 5.0.

The studied strains exhibited similar pectinolytic activity to that previously reported for $A$. pullulans at $\mathrm{pH} 3.5$ and $12{ }^{\circ} \mathrm{C}$, which has already been characterized (Merín et al., 2011). Consequently, considering that this is the first study reporting pectinase production by $R$. dairenensis and Cr. saitoi, both strains (GM-15 and GM-4) were selected to characterize their enzymatic activity under wine-like conditions.

Because of the interest in cold-active enzymes, pectinolytic and other hydrolytic activities useful in vinification were further assayed in yeast enzymatic extracts produced at $\mathrm{pH} 3.5$ and $12{ }^{\circ} \mathrm{C}$. Pectinase activity in both strains was significantly higher than activity showed by $T$. delbrueckii BTd259 control strain, particularly in $R$. dairenensis GM-15 (1.104 U/mL) (Table 2), and also higher than pectinolytic activities produced by other yeasts, like Saccharomyces and Zygoascus hellenicus strains (0.100-0.679 U/mL), even at 30 or $50{ }^{\circ} \mathrm{C}$ (Oliveira et al., 2006; Ahansal et al., 2008).

Cellulase and hemicellulase enzymes degrade cellulose and hemicelluloses, respectively, present in grape cell walls. Consequently, they are responsible for an increase in the extraction of juice and color, and for improvement in the clarification of wines (Romero-Cascales et al., 2008). Of the secondary enzymes assayed, only cellulase activity was detected in GM-15 enzymatic extract with a considerable activity $(0.549 \mathrm{U} / \mathrm{mL})$ at $12{ }^{\circ} \mathrm{C}$ (Table 2$)$.

$\beta$-Glucosidase enzymes hydrolyze glycosilated complexes releasing volatile compounds that contribute to wine aroma (Rodríguez et al., 2007). However, commercial pectinases containing $\beta$-glucosidases may cause a loss of color in red wines because some of these enzymes are able to degrade anthocyanins, glycosilated polyphenols that are mainly responsible for the red color of wine (RomeroCascales et al., 2008). The fact that $\beta$-glucosidase was not detected in the enzymatic systems analyzed (Table 2 ) is a positive feature when the yeast enzymes are applied to red winemaking.
Protease activity was also assayed on plate at $12{ }^{\circ} \mathrm{C}$. Neither of the strains secreted proteases into the medium, unlike the T. delbrueckii BTd259 control strain (Table 2).

\section{Effect of ethanol and sulfur dioxide on pectinolytic activity}

Wine is a complex system that presents a combination of factors such as $\mathrm{pH}$, temperature, ethanol and $\mathrm{SO}_{2}$, among others. Since the sum of the responses of each of the single parameters does not necessarily predict the combined response of such parameters (Grimaldi et al., 2005), the combined effect of ethanol and sulfur dioxide on enzymatic activity should be studied.

To acquire high quality products, the enology sector uses different technologies like low temperature vinification (Gómez-Míguez et al., 2007; Fleet, 2008) and due to the potential value of cold-active enzymes, research on these enzymes is increasing conspicuously in these years. Therefore, the individual and combined effect of $15 \%(\mathrm{v} / \mathrm{v})$ ethanol and $120 \mathrm{mg} / \mathrm{L} \mathrm{SO}_{2}$ on pectinolytic activity was assessed at 12 and $28^{\circ} \mathrm{C}$ (Figure 3). At $12{ }^{\circ} \mathrm{C}, 15 \%$ (v/v) ethanol and $120 \mathrm{mg} / \mathrm{L} \mathrm{SO}_{2}$ as individual parameters hardly affected pectinolytic activity (retaining around $80-90 \%$ of relative activity), except for GM-4 pectinase, which was greatly inhibited by ethanol (conserving only $12 \%$ of relative activity). The combination of ethanol and $\mathrm{SO}_{2}$ reduced pectinolytic activity to 50 and $70 \%$, for GM-4 and GM- 15 , respectively.

At $28^{\circ} \mathrm{C}$, the ethanol concentration assayed reduced the pectinolytic activity of GM-4 by $50 \%$ and of GM- 15 only by $20 \%$. Nevertheless, emphasis must be laid in the fact that at the $\mathrm{SO}_{2}$ concentration assayed $(120 \mathrm{mg} / \mathrm{L}$, the highest concentration generally observed in must at the beginning of the fermentation), activity increased by $33 \%$ (GM-4) and 22\% (GM-15), compared with the reference activity. The combination of ethanol and $\mathrm{SO}_{2}$ assayed at $28{ }^{\circ} \mathrm{C}$ slightly reduced GM- 4 activity by $20 \%$, while it enhanced GM-15 activity by $30 \%$ (Figure 3 ).

With respect to GM-4 pectinase activity, the combined effect of the two parameters produced a relative activity intermediate between the response to ethanol and $\mathrm{SO}_{2}$ as single parameters at both temperatures. On the other hand, GM-15 pectinase behaved differently at the two tem-

Table 2 - Hydrolytic activities of enological interest of selected pectinolytic strains assessed at low temperature $\left(12{ }^{\circ} \mathrm{C}\right)$ and grape $\mathrm{pH}(3.5)$.

\begin{tabular}{lccc}
\hline Hydrolytic activities of enological interest & Cr. saitoi GM-4 & R. dairenensis GM-15 & T. delbrueckii BTd259 $^{\dagger}$ \\
\hline Pectinase (U/mL) & $0.858 \pm 0.087^{\mathrm{b}}$ & $1.104 \pm 0.034^{\mathrm{c}}$ & $0.423 \pm 0.031^{\mathrm{a}}$ \\
Cellulase $(\mathrm{U} / \mathrm{mL})$ & $\mathrm{ND}$ & $0.549 \pm 0.068$ & $\mathrm{ND}$ \\
Xylanase $(\mathrm{U} / \mathrm{mL})$ & $\mathrm{ND}$ & $\mathrm{ND}$ & $0.243 \pm 0.005$ \\
$\beta$-Glucosidase $(\mathrm{U} / \mathrm{mL})$ & $\mathrm{ND}$ & $\mathrm{ND}$ & $0.0026 \pm 0.0004$ \\
Protease $($ skim milk and gelatin) & - & - & + \\
\hline
\end{tabular}

${ }^{\dagger}$ Control strain for enzymatic activities (Maturano et al., 2012).

Different superscript letters within the same row indicate significant differences according to the LSD test $(\mathrm{p}<0.05)$. Data are mean values $(\mathrm{n}=3) \pm \mathrm{SD}$. ND - not detected. 


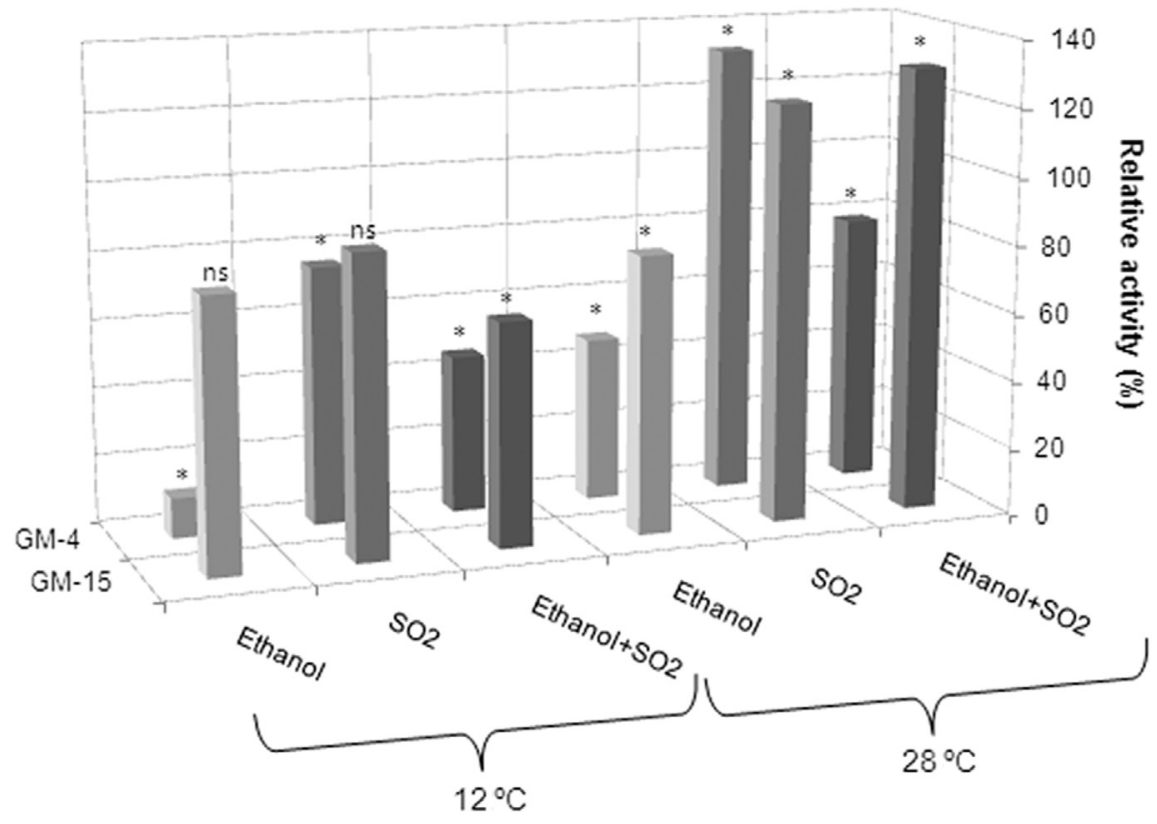

Figure 3 - Relative pectinolytic activity of $\mathrm{Cr}$. saitoi GM-4 and R. dairenensis GM-15 assayed at 12 and $28{ }^{\circ} \mathrm{C}$ in presence of $15 \%$ (v/v) ethanol or $120 \mathrm{mg} / \mathrm{L} \mathrm{SO}{ }_{2}$ or a combination of both compounds. Reference activity $\left(100 \%\right.$ of relative activity): $0.736 \pm 0.071 \mathrm{U} / \mathrm{mL}$ at $12^{\circ} \mathrm{C}$ and $1.349 \pm 0.133 \mathrm{U} / \mathrm{mL}$ at $28{ }^{\circ} \mathrm{C}$ for $\mathrm{Cr}$. saitoi GM-4, and $0.972 \pm 0.083 \mathrm{U} / \mathrm{mL}$ at $12{ }^{\circ} \mathrm{C}$ and $1.483 \pm 0.091 \mathrm{U} / \mathrm{mL}$ at $28^{\circ} \mathrm{C}$ for $R$. dairenensis GM-15. (*): significant difference, (ns): not significant, according to the LSD test $(\mathrm{n}=3, \mathrm{p}<0.05)$. In all cases SD was lower than $10 \%$.

peratures assayed. Temperature seemed to affect the relative activity in presence of ethanol and $\mathrm{SO}_{2}$, since at $12{ }^{\circ} \mathrm{C}$ the activity was negatively affected, but unexpectedly, at $28^{\circ} \mathrm{C}$ the enzymatic activity was slightly increased. At the higher temperature, $\mathrm{SO}_{2}$ probably counteracts the negative effect of ethanol on the relative activity. This could be explained by the unique ability of $\mathrm{SO}_{2}$ to act as an oxidizing or a reducing agent that enables it either to inactivate enzyme systems by splitting their disulfide linkages (Cecil and Wake, 1962) or activate certain hydrolytic enzyme systems, probable by bringing about conformational changes (Malhotra and Hocking, 1976).

Different responses of related hydrolytic activities to these compounds have been reported. Ethanol concentrations of $12 \%(\mathrm{v} / \mathrm{v})$ have been found to decrease polygalacturonase activity from S. cerevisiae (Fernández-González et al., 2004), protease activity from Ananas comosus (Esti et al., 2011) and $\alpha$-L-rhamnosidase activity from Aspergillus terreus (Gallego et al., 2001) to around 20$50 \%$. Likewise, $15 \%(\mathrm{v} / \mathrm{v})$ ethanol decreased the activity of $\beta$-glucosidases and $\beta$-xylosidases from wine yeasts to around $35 \%$ and $55 \%$, respectively (Rodríguez et al., 2007). Conversely, ethanol concentrations of 15 to $20 \%$ $(\mathrm{v} / \mathrm{v})$ produced significant increases $(150-500 \%$ relative activity) in $\beta$-glucosidase (Barbagallo et al., 2004) and $\beta$ xylosidase (Rodríguez et al., 2007) activities from wine yeasts.

$\mathrm{SO}_{2}$ has been reported to strongly inhibit protease activity from Ananas comosus (Esti et al., 2011). Neverthe- less, polygalacturonase (Fernández-González et al., 2004) and $\alpha$-L-rhamnosidase (Gallego et al., 2001) activities were not affected by $50 \mathrm{mg} / \mathrm{L} \mathrm{SO}_{2}$. Rodríguez et al. (2007) observed that $\beta$-glucosidase activity from wine yeasts was not affected by $150 \mathrm{mg} / \mathrm{L} \mathrm{SO}_{2}$, which agrees with our results that showed a slight increase in pectinolytic activity in presence of $120 \mathrm{mg} / \mathrm{L} \mathrm{SO}_{2}$ compared with the reference activity. However, it is important to mention that the authors cited did not determine the effect of a combination of ethanol and $\mathrm{SO}_{2}$ on the enzyme activities assayed.

These outcomes suggest that application of pectinase of $R$. dairenensis GM-15 in the production of red wine is preferably carried out at traditional temperatures $\left(26-28{ }^{\circ} \mathrm{C}\right)$; although in vinifications at low temperature $\left(12{ }^{\circ} \mathrm{C}\right)$ it would still retain high residual activity.

In conclusion, the current study has demonstrated that inoculation of pectinolytic yeasts or addition of pectinases in the vinification process is necessary since they do not naturally occur during wine fermentation. Our results also suggest that pectinolytic yeasts should be isolated from the grape surface. To our knowledge, this is the first report on pectinase production by $C r$. saitoi and $R$. dairenensis species. The outcomes of the combined effect of ethanol and $\mathrm{SO}_{2}$ at two possible fermentation temperatures on the pectinolytic activity indicated that the studied enzymes, particularly GM-15 pectinase, performed satisfactorily under wine-like conditions: at low $\mathrm{pH}(3.5)$, at low $\left(12{ }^{\circ} \mathrm{C}\right)$ and traditional $\left(28{ }^{\circ} \mathrm{C}\right)$ temperature in red winemaking, and in the presence of potential enzymatic inhibitors like ethanol 
$(15 \%[\mathrm{v} / \mathrm{v}])$ and $\mathrm{SO}_{2}(120 \mathrm{mg} / \mathrm{L})$. R. dairenensis $\mathrm{GM}-15$ also produced cellulase activity at low temperature and at grape $\mathrm{pH}$, and did not produce $\beta$-glucosidase activity avoiding risks of color loss when it is used in red winemaking. Further studies regarding effects of these enzymes on wine processing and quality are needed in order to propose them in enology.

\section{Acknowledgments}

This research was supported by grants from CONICET (PIP $\mathrm{N}^{\circ} 11220110100823$ project); SECTyP-UNCuyo ( $\mathrm{N}^{\circ}$ 06/L116 project) and I+D (UNCuyo) program, and ANPCyT-MINCYT (PICT 2010 $\mathrm{N}^{\circ} 0847$ project). The authors wish to thank Raúl Carrión for supplying grape samples, and Dr. Lucía Mendoza and Raúl Raya $(\mathrm{PhD})$ for their assistance in yeast identification. This work is dedicated to the memory of Dr. Marta Farías.

\section{References}

Ahansal L, Ben Sassi A, Martini A et al. (2008) Biodiversity of yeasts isolated from the indigenous forest of Argan (Argania spinosa (L.) Skeels) in Morocco. World J Microbiol Biotechnol 24:777-782.

Alimardani-Theuil P, Gainvors-Claisse A, Duchiron F (2011) Yeasts: An attractive source of pectinases-From gene expression to potential applications: A review. Process Biochem 46:1525-1537.

Arévalo-Villena M, Úbeda Iranzo JF, Briones Pérez MI (2007) $\beta$-Glucosidase activity in wine yeasts: Application in enology. Enzyme Microb Technol 40:420-425.

Barata A, Malfeito-Ferreira M, Loureiro V (2012) The microbial ecology of wine grape berries. Int J Food Microbiol 153:243-259.

Barbagallo RN, Spagna G, Palmeri R et al. (2004) Selection, characterization and comparison of $\beta$-glucosidase from mould and yeasts employable for enological application. Enzyme Microb Technol 35:58-66.

Buzzini P, Martini A (2002) Extracellular enzymatic activity profiles in yeast and yeast-like strains isolated from tropical environments. J Appl Microbiol 93:1020-1025.

Cecil R, Wake RG (1962) The reactions of inter- and intra-chain disulphide bonds in protein with sulphite. Biochem J 82:401.

Charoenchai C, Fleet GH, Henschke PA et al. (1997) Screening of non-Saccharomyces wine yeasts for the presence of extracellular hydrolytic enzymes. Aust J Grape Wine Res 3:2-8.

Cocolin L, Bisson LF, Mills DA (2000) Direct profiling of the yeast dynamics in wine fermentations. FEMS Microbiol Lett 189:81-87.

Esti M, Benucci I, Liburdi K et al. (2011) Effect of wine inhibitors on free pineapple stem bromelain activity in a model wine system. J Agric Food Chem 59:3391-3397.

Federici F (1988) Pectic enzyme production by Cryptococcus albidus var. albidus on olive vegetation waters enriched with sunflower calathide meal. Biol Wastes 25:291-301.

Fernández M, Úbeda JF, Briones AI (2000) Typing of nonSaccharomyces yeasts with enzymatic activities of interest in wine-making. Int J Food Microbiol 59:29-36.
Fernández-González M, Úbeda JF, Vasudevan TG et al. (2004) Evaluation of polygalacturonase activity in Saccharomyces cerevisiae wine strains. FEMS Microbiol Lett 237:261-266.

Fleet GH (2008) Wine yeasts for the future. FEMS Yeast Res 8:979-995.

Gallego MV, Piñaga F, Ramón D et al. (2001) Purification and characterization of an $\alpha$-L-rhamnosidase from Aspergillus terreus of interest in winemaking. Food Chem Toxicol 66:204-209.

Gómez-Míguez M, González-Miret ML, Heredia FJ (2007) Evolution of colour and anthocyanin composition of Syrah wines elaborated with pre-fermentative cold maceration. J Food Eng 79:271-278.

Grimaldi A, Bartowsky E, Jiranek V (2005) A survey of glycosidase activities of commercial wine strains of Oenococcus oeni. Int J Food Microbiol 105:233-244.

Kurtzman CP, Robnett CJ (1998) Identification and phylogeny of ascomycetous yeasts from analysis of nuclear large subunit (26S) ribosomal DNA partial sequences. Antonie Van Leeuwenhoek 73:331-371.

Malhotra SS, Hocking D (1976) Biochemical and cytological effects on sulphur dioxide on plant metabolism. New Phytol 76:227-237

Martín MC, Morata de Ambrosini VI (2014) Effect of a coldactive pectinolytic system on colour development of Malbec red wines elaborated at low temperature. Int J Food Sci Technol 49:1893-1901.

Maturano YP, Rodríguez LA, Toro ME et al. (2012) Multienzyme production by pure and mixed cultures of Saccharomyces and non-Saccharomyces yeasts during wine fermentation. Int J Food Microbiol 155:43-50.

Merín MG, Mendoza LM, Farías ME et al. (2011) Isolation and selection of yeasts from wine grape ecosystem secreting cold-active pectinolytic activity. Int J Food Microbiol 147:144-148.

Merín MG, Mendoza LM, Morata de Ambrosini VI (2014) Pectinolytic yeasts from viticultural and enological environments: novel finding of Filobasidium capsuligenum producing pectinases. J. Basic Microbiol 54:835-842.

Miller GL (1959) Use of dinitrosalicylic acid reagent for determination of reducing sugar. Anal Chem 31:426-428.

Nakagawa T, Nagaoka T, Taniguchi S et al. (2004) Isolation and characterization of psychrophilic yeasts producing coldadapted pectinolytic enzymes. Lett Appl Microbiol 38:383387.

Oliveira KF, Malavolta L, Souza CS et al. (2006) Pectinolytic activity secreted by yeasts isolated from fermented citrus molasses. J Appl Microbiol 100:633-640.

Pallmann C, Brown JA, Olineka TL et al. (2001) Use of WL medium to profile native flora fermentations. Am J Enol Vitic 52:198-203.

Rantsiou K, Campolongo S, Alessandria V et al. (2013) Yeast populations associated with grapes during withering and their fate during alcoholic fermentation of high-sugar must. Aust J Grape Wine Res 19:40-46.

Rodríguez ME, Lopes C, Vlales S et al. (2007) Selection and preliminary characterization of $\beta$-glycosidases producer Patagonian wild yeasts. Enzyme Microb Technol 41:812-820.

Romero-Cascales I, Fernández-Fernández JI, Ros-García JM et al. (2008) Characterisation of the main enzymatic activities present in six commercial macerating enzymes and their ef- 
fects on extracting colour during winemaking of Monastrell grapes. Int J Food Sci Technol 43:1295-1305.

Sahay S, Hamid B, Singh P et al. (2013) Evaluation of pectinolytic activities for oenological uses from psychrotrophic yeasts. Lett Appl Microbiol 57:115-121.

Taskin M (2013) Co-production of tannase and pectinase by free and immobilized cells of the yeast Rhodotorula glutinis MP-10 isolated from tannin-rich persimmon (Diospyros $k a k i$ L.) fruits. Bioproc Biosyst Eng 36:165-172.
Turchetti B, Buzzini P, Goretti M et al. (2008) Psychrophilic yeasts in glacial environments of Alpine glaciers. FEMS Microbiol Ecol 63:73-83.

Urso R, Rantsiou K, Dolci P et al. (2008) Yeast biodiversity and dynamics during sweet wine production as determined by molecular methods. FEMS Yeast Res 8:1053-1062.

Vaz AB, Rosa LH, Vieira ML et al. (2011) The diversity, extracellular enzymatic activities and photoprotective compounds of yeasts isolated in antarctica. Braz J Microbiol 42:937-947.

Associate Editor: Susana Marta Isay Saad

All the content of the journal, except where otherwise noted, is licensed under a Creative Commons License CC BY-NC. 